\title{
Fungi Identification in Preservative Liquids of Cadaver at Anatomy Laboratory of Faculty of Medicine Maranatha Christian University Bandung
}

\author{
Mochamad H Herdiman*, Triswaty Winata**, Tediany Pramesti***, \\ Imam G Alam*** \\ *Department of Anatomy Faculty of Medicine Maranatha Christian University \\ ** Department of Microbiology Faculty of Medicine Maranatha Christian University \\ *** Faculty of Medicine Maranatha Christian University \\ Jl. Suria Sumantri No.65 Bandung - Jawa Barat \\ Email: h.herdiman@yahoo.com
}

\begin{abstract}
Cadaver is an important learning media for students of the Faculty of Medicine. Although the cadaver has undergone a preservation process, sometimes the preservative liquids used only protects the cadaver, and does not inhibit the fungal growth. Based on previous research, the fungus found in cadaveric preparations are pathogenic. The objectives of this study were to identify the growing fungus on the cadaver preservative liquid at the Anatomy Laboratory of the Faculty of Medicine, Maranatha Christian University. This is a descriptive experimental study. Samples were taken from three cadaver tubs. Subsequently, the sample was inoculated on Sabouraud's Dextrose Agar and Chromagar medium in a petridish and incubated at room temperature $\left(25{ }^{9}\right)$ for seven days. After seven days, the morphology of the fungus was observed macroscopically and microscopically. We found Aspergillus sp., Penicillium sp., Epidermophyton sp., and Candida sp on the samples. The study was conducted in December 2017-January 2018 at the Microbiology Laboratory, Faculty of Medicine, Maranatha Christian University and Microbiology Laboratory, Faculty of Medicine, Padjadjaran University.
\end{abstract}

Keywords: fungi, cadaver, preservative liquid 


\title{
Identifikasi Jamur pada Cairan Pengawet Kadaver di Laboratorium Anatomi Fakultas Kedokteran Universitas Kristen Maranatha Bandung
}

\author{
Mochamad H Herdiman*, Triswaty Winata**, Tediany Pramesti***, \\ Imam G Alam***
}

\author{
*Bagian Anatomi Fakultas Kedokteran Universitas Kristen Maranatha \\ **Bagian Mikrobiologi Fakultas Kedokteran Universitas Kristen Maranatha \\ *** Fakultas Kedokteran Universitas Kristen Maranatha \\ J1. Suria Sumantri No.65 Bandung - Jawa Barat \\ Email: h.herdiman@yahoo.com
}

\begin{abstract}
Abstrak
Kadaver merupakan media pembelajaran yang penting bagi mahasiswa fakultas kedokteran. Meskipun kadaver telah mengalami proses pengawetan, terkadang formula cairan pengawet yang digunakan hanya mampu menjaga kadaver bertahan lama tanpa menghambat pertumbuhan jamur. Berdasarkan penelitian sebelumnya, jamur yang ditemukan pada sediaan kadaver merupakan jamur patogen yang menimbulkan penyakit. Tujuan penelitian ini adalah untuk mengidentifikasi jamur yang tumbuh pada sediaan kadaver di Laboratorium Anatomi Fakultas Kedokteran Universitas Kristen Maranatha. Desain penelitian menggunakan desain eksperimental deskriptif. Sampel diambil dari masing-masing bak rendaman kadaver. Selanjutnya, sampel diinokulasi pada medium Sabouraud's Dextrose Agar dan Chromagar di dalam cawan petri dan diinkubasi pada suhu ruangan $\left(25^{\circ} \mathrm{C}\right)$ selama tujuh hari. Setelah tujuh hari, morfologi jamur diamati secara makroskopis dan mikroskopis. Dari hasil pengamatan, didapatkan beberapa jenis jamur dari biakkan sampel yaitu Aspergillus sp., Penicillium sp., Epidermophyton sp., dan Candida sp. Penelitian ini dilakukan pada bulan Desember 2017Januari 2018 di Laboratorium Mikrobiologi Fakultas Kedokteran Universitas Kristen Maranatha dan Laboratorium Mikrobiologi Fakultas Kedokteran Universitas Padjajaran.
\end{abstract}

Kata kunci: jamur, kadaver, cairan pengawet 


\section{Pendahuluan}

Kadaver digunakan untuk mempelajari anatomi manusia secara nyata dan dalam bentuk tiga dimensi. Mahasiswa dapat mempelajari bagian tubuh manusia dari bagian luar sampai dalam, seperti pembuluh darah, saraf, otot, dan organ dalamnya. Pemahaman anatomi menggunakan kadaver tetap tidak dapat digantikan dengan metoda pembelajaran lainnya karena dengan kadaver, anatomi manusia menjadi lebih nyata. ${ }^{1}$

Salah satu masalah yang sering timbul pada rendaman kadaver di laboratorium anatomi antara lain tumbuhnya mikroorganisme yang tidak diinginkan, salah satunya adalah jamur. ${ }^{2}$ Meskipun kadaver telah mengalami proses pengawetan, terkadang formula cairan pengawet yang digunakan hanya mampu menjaga jaringan kadaver bertahan lama tanpa menghambat pertumbuhan jamur. $^{2}$

Pada penelitian yang dilakukan oleh Yaragalla et al (2017) ditemukan adanya Aspergillus spp., Penicillium spp., Candida spp., dan Trichophyton spp. pada kadaver yang telah terfiksasi oleh formalin. Pada penelitian lain di Faculty of Medicine, Thammasat University, Thailand tahun 2008 ditemukan Penicillium spp., Chrysonilia sitophila, dan Trichoderma spp. Reed et al (1993) menemukan adanya Aspergillus, Blastomyces, Coccidioides, dan Histoplasma pada kadaver yang diteliti. Elsebai et al (2002) mengidentifikasi jamur yang tumbuh pada kadaver di College of Medicine, University of Al-Anbar, Iraq. Hasilnya ditemukan Aspergillus, Penicillium, Trychophyton, Epidermophyton, dan Cryptococcus. Beberapa jenis jamur yang tumbuh pada kadaver merupakan patogen yang dapat menimbulkan penyakit terutama pada saluran pernafasan. $^{2}$

Tujuan penelitian ini adalah untuk mengidentifikasi jamur yang tumbuh pada sediaan rendaman kadaver di Laboratorium Anatomi Fakultas Kedokteran Universitas Kristen Maranatha.

\section{Metode}

Penelitian ini dilakukan di Laboratorium Anatomi FK-UKM dan Laboratorium Mikrobiologi Lembaga Penelitian Universitas Padjajaran dari bulan desember 2017-januari 2018. Penelitian ini bersifat eksperimental sungguhan dan telah mendapat persetujuan dari Komite Etik Penelitian Kedokteran dan Kesehatan, Fakultas Kedokteran, Universitas Kristen Maranatha berdasarkan SK No 248a/KEP/XII/2017.

Subjek penelitian adalah jamur yang diambil dari cairan pengawet di tiga bak kadaver di Laboratorium Anatomi Fakultas Kedokteran Universitas Kristen Maranatha. Sampel jamur diambil menggunakan pinset dan ditampung menggunakan pot dahak steril. Sampel kemudian dibawa ke Laboratorium Mikrobiologi Universitas Padjadjaran untuk diidentifikasi. 
Sampel jamur diinokulasikan pada medium Saboraud's Dextrose Agar (SDA) dan Chromagar pada cawan petri dengan metode cawan gores (streak plate). Selanjutnya, sampel diinkubasi dalam suhu ruangan selama tujuh hari. Setelah tujuh hari, tumbuh berbagai jenis jamur pada kultur campuran. Jamur kemudian diidentifikasi secara makroskopis.

Setelah tumbuh koloni jamur, selanjutnya dilakukan analisis jamur secara mikroskopis, dengan cara meneteskan satu tetes akuades pada kaca objek menggunakan pipet pasteur. Kemudian, sampel jamur pada biakkan SDA diambil menggunakan oese yang telah dibakar dan diletakkan di atas akuades tersebut. Selanjutnya, ditambahkan satu tetes larutan Lactophenol Cotton Blue (LPCB) sebagai pewarna dan ditutup menggunakan cover glass. Preparat kemudian diamati di bawah mikroskop listrik binokuler. ${ }^{3}$

Analisis data dilakukan secara deskriptif dan disajikan dalam bentuk tabel.

\section{Hasil}

Penelitian identifikasi jamur yang didapatkan dari rendaman kadaver Laboratorium Anatomi Universitas Kristen Maranatha memberikan hasil yang disajikan pada tabel 1 di bawah ini.

\section{Tabel 1 Hasil Identifikasi Jamur Pada Tiga Bak Rendaman Kadaver di Laboratorium Anatomi Fakultas Kedokteran Universitas Kristen Maranatha}

\begin{tabular}{|c|c|c|c|c|}
\hline \multirow[t]{2}{*}{ Sampel } & \multicolumn{3}{|c|}{ Hasil Pemeriksaan } & \multirow[t]{2}{*}{ Kesimpulan } \\
\hline & Wet Mount & $\begin{array}{c}\text { Kultur SDA } \\
\text { (koloni) }\end{array}$ & $\begin{array}{l}\text { Chromagar } \\
\text { (koloni) }\end{array}$ & \\
\hline Bak 1 & $\begin{array}{l}\text { Sel yeast }(+) \\
\text { Hifa }(+)\end{array}$ & Penicillium sp. (+) & $\begin{array}{l}\text { C.glabrata/parapsilosis }(+) \\
\text { Penicillium } \mathrm{sp} .(+) \\
\text { Aspergillus } \mathrm{sp} .(+)\end{array}$ & $\begin{array}{l}\text { Penicillium } \text { sp. }(+) \\
\text { Aspergillus } \mathrm{sp} .(+) \\
\text { C.glabrata/parapsilosis }(+)\end{array}$ \\
\hline Bak 2 & $\begin{array}{l}\text { Sel yeast }(+) \\
\text { Hifa }(+)\end{array}$ & $\begin{array}{l}\text { Penicillium sp.(+) } \\
\text { Aspergillus sp. (+) }\end{array}$ & $\begin{array}{l}\text { C.glabrata/parapsilosis }(+) \\
\text { Penicillium } \mathrm{sp} .(+) \\
\text { Aspergillus } \mathrm{sp} .(+)\end{array}$ & $\begin{array}{l}\text { Penicillium } \mathrm{sp} .(+) \\
\text { Aspergillus } \mathrm{sp} .(+) \\
\text { C.glabrata/parapsilosis }(+)\end{array}$ \\
\hline Bak 3 & Hifa (+) & $\begin{array}{l}\text { Penicillium } \mathrm{sp} .(+) \\
\text { Epidermophyton } \mathrm{sp} .(+) \\
\text { Koloni yeast }(+)\end{array}$ & $\begin{array}{l}\text { C.glabrata/parapsilosis }(+) \\
\text { Penicillium sp. }(+) \\
\text { Epidermophyton } \mathrm{sp} .(+)\end{array}$ & $\begin{array}{l}\text { Penicillium sp. }(+) \\
\text { Epidermophyton } \mathrm{sp} .(+) \\
\text { C.glabrata/parapsilosis }(+)\end{array}$ \\
\hline
\end{tabular}

Tabel 1 menunjukkan bahwa terdapat berbagai jenis jamur yang bervariasi pada setiap bak kadaver. Pada bak 1 dan 2 didapatkan jamur Penicillium sp. (+), Aspergillus sp., $C$. glabrata/parapsilosis, sedangkan pada bak 3 didapatkan jamur Penicillium sp., Epidermophyton sp., C. glabrata/parapsilosis. Gambaran makroskopis dan mikroskopis masing-masing jamur disajikan pada gambar 1, 2, dan 3. 


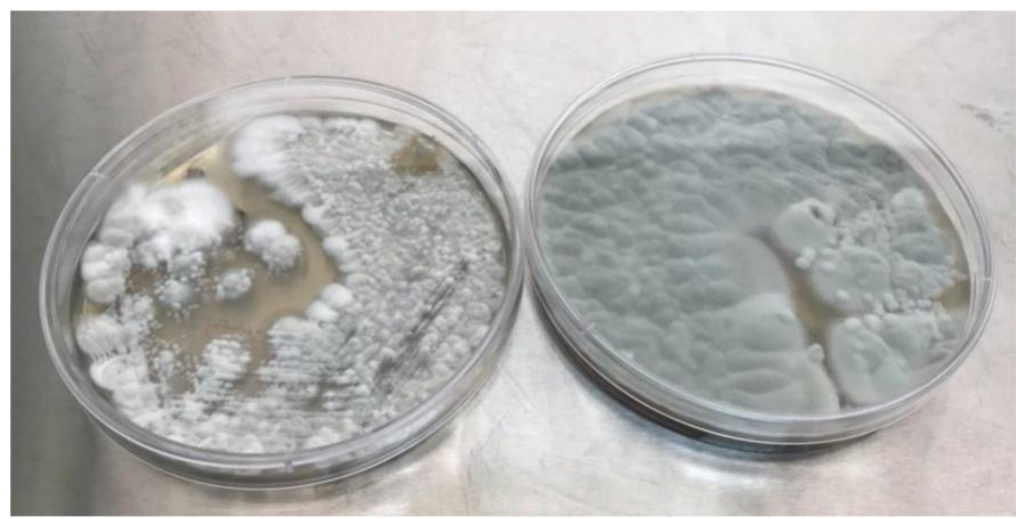

Gambar 1 Koloni jamur dari bak 1: Pada cawan petri chromagar (kiri) tampak koloni Penicillium sp. Candida parapsilosis/glabrata, dan Aspergillus sp. Pada cawan petri SDA (kanan), tampak koloni dari Penicillium sp.

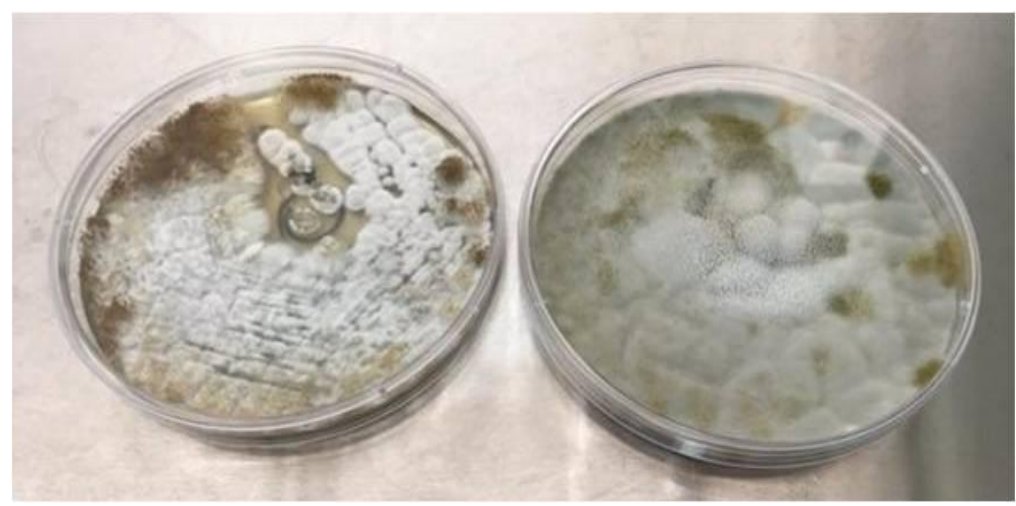

Gambar 2. Koloni jamur dari bak 2. Pada cawan petri chromagar (kiri) tampak koloni Penicillium sp., Candida parapsilosis/glabrata, dan Aspergillus sp. berwarna kehitaman. Pada cawan petri SDA (kanan) tampak koloni Penicillium sp. dan Aspergillus sp.

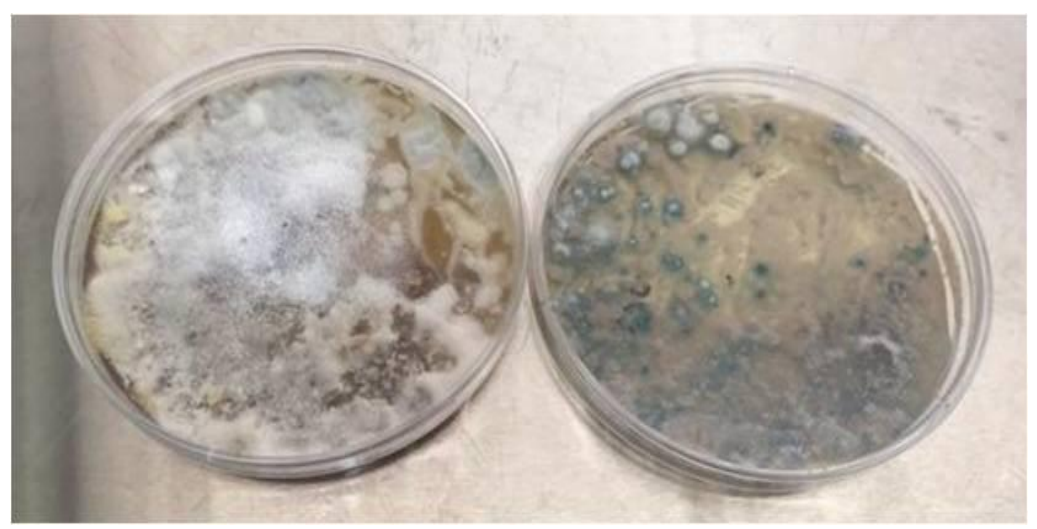

Gambar 3 Koloni jamur dari bak 3. Pada cawan petri chromagar (kiri) tampak koloni Penicillium sp., Candida parapsilosis/glabrata, dan Epidermophyton sp. Pada cawan petri SDA (kanan) tampak koloni Penicillium sp. dan Epidermophyton sp. 

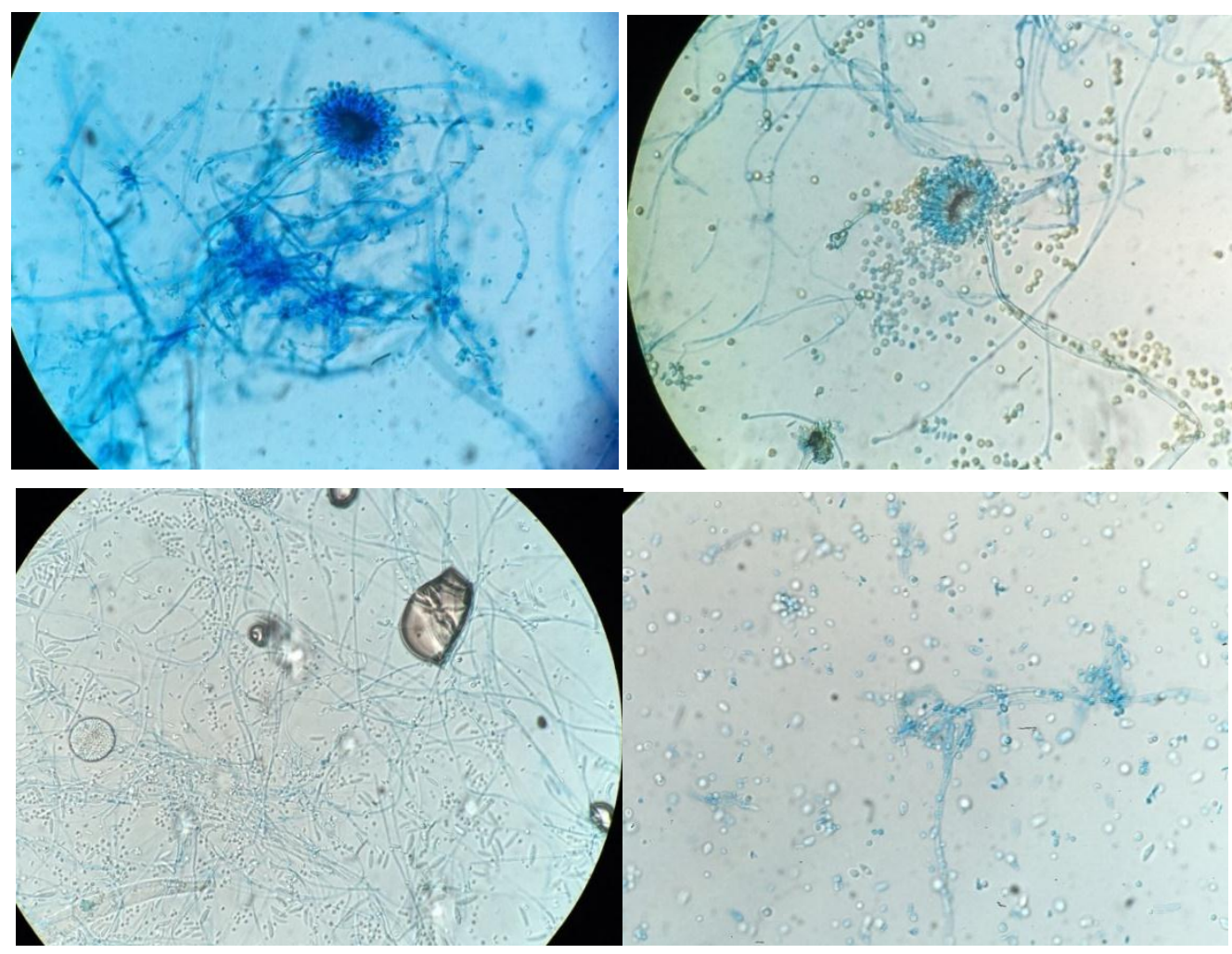

Gambar 4 Gambaran mikroskopis dari jamur yang didapatkan: Aspergillus sp (atas), Epidermophyton sp. (kiri bawah), dan Penicillium sp. (kanan bawah)

\section{Diskusi}

Berdasarkan hasil penelitian, diidentifikasi jamur Penicillium sp., Aspergillus sp., C.glabrata/parapsilosis, dan Epidermophyton sp. dari cairan pengawet pada bak rendaman kadaver di laboratorium anatomi Fakultas Kedokteran Universitas Kristen Maranatha Bandung. Berdasarkan penelitian-penelitian sebelumnya, jamur Aspergillus sp. dan Penicillium sp. adalah jamur yang paling sering ditemukan pada kadaver dan pada penelitian ini ditemukan pada seluruh rendaman bak kadaver, sedangkan jamur Candida sp. dan Epidermophyton sp. bukan merupakan jamur yang sering ditemukan pada sediaan pengawetan kadaver. ${ }^{4}$ Candida sp. pernah ditemukan pada penelitian Yaragalla (2017) pada kadaver yang telah terfiksasi oleh formalin, sedangkan Epidermophyton sp. pernah ditemukan oleh Elsebai pada kadaver di College of Medicine, University of Al-Anbar, Iraq. ${ }^{2}$

Aspergillus sp., Penicillium sp., Epidermophyton sp., dan Candida sp., merupakan jamur yang dapat ditemukan pada udara bebas. Jamur tersebut dapat menempel pada rendaman kadaver bahkan pada kadaver itu sendiri yang masuk melalui jalur ventilasi di ruang penyimpanan kadaver. Selain itu mungkin penggantian cairan rendaman yang tidak rutin dapat memengaruhi kualitas dari formalin sehingga tidak dapat menginhibisi pertumbuhan jamur. 
Sistem kipas pengeluaran udara (exhaust) juga mungkin berperan dalam masuknya jamur ke dalam ruangan penyimpanan kadaver. Epidermophyton khususnya terdapat pada lapisan kulit luar manusia, sehingga mungkin masih dapat menempel pada kulit kadaver. ${ }^{4}$

Penelitian ini menjadi dasar untuk penelitian selanjutnya untuk meninjau kembali kondisi ruangan dan sistem sirkulasi udara di Laboratorium Anatomi FK-UKM. Pada saat ini ternyata masih terdapat ventilasi udara yang berhubungan langsung dengan udara bebas di luar laboratorium sehingga formulasi konsentrasi cairan pengawet yang mungkin berubah, serta kondisi kelembaban udara yang mungkin cukup tinggi.

Formulasi cairan pengawet kadaver sangat berperan penting dalam menghambat pertumbuhan jamur. Cairan formalin selain berperan sebagai pengawet juga dapat menginhibisi pertumbuhan jamur. Salah satu efek samping formalin jangka panjang adalah terjadinya kanker, sehingga penelitian ini diharapkan dapat menjadi dasar untuk penelitian selanjutnya dalam membuat formulasi yang tepat untuk pengawet kadaver dengan konsentrasi formalin yang minimal yang masih efektif dalam menghambat pertumbuhan jamur. ${ }^{5-8}$

Pengawet kadaver juga dapat ditambahkan cairan fenol. Telah diketahui bahwa fenol memiliki efek antijamur sehingga sering digunakan sebagai campuran pada larutan antiseptik. Pada beberapa penelitian penambahan cairan fenol pada cairan pengawet kadaver terbukti lebih efektif dalam menghambat pertumbuhan jamur, sehingga ke depannya penambahan cairan fenol di rendaman kadaver Laboratorium Anatomi FK-UKM diharapkan dapat menghambat pertumbuhan jamur. ${ }^{8-11}$

Jamur yang terdapat pada rendaman kadaver tentu saja seiring dengan perjalanan waktu akan merusak kualitas dari kadaver itu sendiri, dan yang paling berbahaya dapat menyebabkan penyakit pada individu yang bekerja maupun belajar di laboratorium anatomi, khususnya bila terjadi kondisi imunosupresi. ${ }^{12,13}$

Beberapa contoh penyakit yang cukup berbahaya yang dapat disebabkan oleh infeksi jamur adalah pneumonia, selain infeksi pada kulit atau jaringan tubuh lainnya. Oleh karena itu, dibutuhkan upaya proteksi diri sebelum melakukan kontak dengan kadaver yaitu dengan menggunakan masker dan sarung tangan pelindung. ${ }^{10}$

\section{Simpulan}

Jamur yang teridentifikasi pada rendaman kadaver di Laboratorium Anatomi Fakultas Kedokteran Universitas Kristen Maranatha adalah Aspergillus sp., Penicillium sp., Candida sp., dan Epidermophyton sp. 


\section{Daftar Pustaka}

1. Prakash, Prabhu L, Rai R, D'Costa S, Jiji PJ, Singh G. Cadavers as teachers in medical education: knowledge is the ultimate gift of body donors. Singapore Med J. 2007;48(3):186.

2. Lakchayapakorn K, Tharasub C, Tiengtip R. Analysis of fungi that grow on formalin-fixed human cadavers at Thammasat University. Thammasat Int J Sc Tech. 2008;13(4): 25-31.

3. Dugan FM. The identification of fungi: an illustrated introduction with keys, glossary, and guide to literature. Amer Phytophathological Society. Minnesota:St. Paul; 2006. p. 136-70. Cited at: December 2017.

4. Sri-indrasutdhi V, Uepattanakit J, Sommatas A. Investigation of airborne fungi and their ability to grow on formalin-fixed human cadavers. Mycosphere. 2015;6(6):729-36.

5. Alsharif MHK, Musthafa M, Elamin AY, Ibnouf EO, Taha KM, Alfaki MA, et al. A brief review on the principles of human cadaver preservation and monitoring of microbiological degradation. For Med and Anat Res. 2017;5:19-31.

6. Dewan SR, Bahar S. Potential health hazards for students exposed to formaldehyde in the gross anatomy laboratory. National Environment Health Association. 2011;74(6):36-40.

7. Viskasari PK, Lucky P, Haryanto A. The use of lower formalin-containing embalming solution for anatomy cadaver preparation. Med J Indones. 2012;21(4):203-7.

8. Brenner E. Human body preservation - old and new techniques. J Anat. 2014;224:316-44.

9. Rogawansamy S, Gaskin S, Taylor M, Pisaniello D. An evaluation of antifungal agents for the treatment of fungal contamination in indoor air environments. Int J Environ Res Public Health. 2015;12:6319-32.

10. McDonnell G, Russell D. Antiseptics and disinfectants: activity, action, and resistance. Clin Microbiol Rev. 1999;12:147-79.

11. Ansari MA, Anurag A, Fatima Z, Hameed S. Natural phenolic compounds: a potential antifungal agents. Microbial Pathogen and Strategies for Combating Them. Méndez-Vilas, A. (Editor). Microbial pathogens and strategies for combating them: science, technology and education. Formatex Research Center,2013. p. 1189-95.

12. Kousha M, Tadi R, Soubani AO. Pulmonary aspergillosis: a clinical review. Eur Respir Rev. 2011;20(121):15674.

13. Khan MSA, Ahmad I, Aqil F, Owais M, Shahid M, Musarrat J. Virulence and pathogenicity of fungal pathogens with special reference to candida albicans. Combating Fungal Infections; 2010. p. 21-45. 